\title{
Krigen indeni: skæbnefortællinger fra revolutionen i Ukraine
}

\author{
Matilde Kimer \\ København: Politikens forlag 2016 \\ 320 sider. ISBN: 9788740028348
}

Anmeldt av Karen-Anna Eggen [MA, informasjonsrådgiver, Den Norske Atlanterhavskomité, eggenkarenanna@dnak.org]

Krigen indeni: skcebnefortcllinger fra revolutionen $i$ Ukraine er skrevet av Dansk Radios (DR) utenrikskorrespondent Matilde Kimer og beskriver utviklingen i Ukrainakrisen fra slutten av 2013 fram til sommeren 2016. I løpet av denne perioden får vi innblikk i tre parallelle historier: Kimers egne skildringer som krigsreporter, beretninger fra husmoren og frivillighetsmedarbeider Anna og studenten og soldaten Bogdans erfaringer. Krigen indeni tegner et sterkt bilde av enkeltmenneskers skjebner i konfliktområder - deres oppturer, nedturer og utrettelige engasjement - og hvordan krig kan splitte så vel et land som familier og nære relasjoner.

Kimer benytter seg av en fortellerstil som vever de tre hovedberetningene sammen på en god måte. Historiene utfyller hverandre, og hoppingen mellom de ulike personene føles naturlig uten at det blir forvirrende. Kimer spiller på bruk av kontraster for å skildre hvordan hverdag og krig glir inn i hverandre. Dette fremgår for eksempel når Kimer først skildrer sine trygge rammer hjemme i Danmark og idylliske stunder sammen med barna, før hun så skifter til - i bokstavelig forstand - å gå over lik på vei til krigssoner i Øst-Ukraina. Kontrasten kommer også frem i historien om Bogdan, som sitter og studerer til eksamen på universitetet sammen med kjæresten Julia, for så å dra ut i krig under dekknavnet Grizlo og bevitne sin beste venns død. Flere ganger beskriver Kimer også, ved bruk av både egne erfaringer og Annas skildringer, rollekonfliktene de som kvinner opplever. Flere ganger blir leseren inkludert i både Kimers og Annas private krangler på hjemmebane hvor de blir møtt med liten forståelse for valget om å vie all energi til krigen, heller enn å være sammen med mann og barn.

Første del av boka fokuserer på Ukrainas hovedstad, Kiev, og tiden rundt Majdan-revolusjonen. Bogdan er med på demonstrasjonene fra første stund som en del av den nasjonalistiske bevegelsen Sitsj. Anna engasjerer seg som frivillig og rives 
ut av husmorstilværelsen, mens Matilde drar ned for å dekke begivenhetene som DRs reporter. Her blir de alle sammen del av det som etter hvert utvikler seg til en blodig konflikt. Vi blir så tatt med over mot del to av boka, som fokuserer på eskaleringen av konflikten med annekteringen av Krim, og krigføringen i de separatist-okkuperte delene av fylkene Donetsk og Lugansk. Her utvikler hovedpersonenes utrettelige engasjement for konflikten seg på ulike måter. Bogdan velger fronten, Matilde journalistikken og Anna utallige timer som frivillig for å hjelpe de ukrainske soldatene $\mathrm{i}$ krig. Samtidig viser boka at slikt engasjement kommer med store omkostninger på det personlige plan. I så måte er dette også en høyst personlig bok, og Kimer beskriver hvordan krigen påvirket relasjonene i egen familie. Krigen som raser inne i hovedpersonenes kropp er også et gjennomgangstema gjennom hele boka.

Kimer er opptatt av å balansere det vestlige og russiske virkelighetsbildet, noe hun klarer bra. Det er krigen og dens ødeleggelser som står i fokus, og ikke nødvendigvis hvem som startet hva. Samtidig får hun tydelig frem hvordan propagandamaskineriet på begge sider har fungert effektivt og skapt et fiendebilde av "de andre». Vi møter for eksempel en eldre kvinne i Donetsk som forklarte Kimer at alle på Majdan var narkomane, og at amerikanske agenter sprøytet narkotika inn i appelsiner som de så delte ut til unge mennesker på uavhengighetsplassen i Kiev.

Et interessant spørsmål er imidlertid om det er mulig å forholde seg til, og skildre, en slik konflikt på en nøytral måte, da den i aller høyeste grad er fanget mellom ulike virkelighetsforståelser. Her er det interessant å merke seg at Kimer utelukkende har valgt ukrainere som hovedpersoner for sin bok. Samtidig redegiør hun for valget $\mathrm{i}$ forordet med at i skildringen av denne krigen har hun valgt Anna og Bogdan «... som representerer det Ukraina, som består av 42 millioner ukrainere, og ikke de knapt 2 millioner innbyggere som bor i de selverklærte folkerepublikkene Donetsk og Lugansk». Kimer reiser også flere ganger til de okkupertes side av konflikten og gir leseren et innblikk i krigens tilstand der. Hun oppsummerer fint håpløsheten i hele konflikten, hvor mennesker på begge sider til syvende og sist ønsker det samme: «fred, fremskritt og ærlige politikere» (s. 86).

Kimer gir stort sett leseren det som trengs av bakgrunnsmateriale, tilleggsinformasjon og viktige momenter for å forstå konflikten. Betydningen av språk og tilhørighet, landets historie og bruken av historie for å skape splittelse, forholdet til Russland, korrupsjonen som giennomsyrer alle samfunnslag i Ukraina, betydningen av storpolitikk for konfliktens utvikling, sivilsamfunnets oppstandelse fra Majdan-asken i form av et enormt frivillig engasjement (her skildret gjennom Anna) og høyrenasjonalismens rolle i Ukraina (her i stor grad skildret gjennom Bogdan/ Grizlo) inkluderes alle som momenter. Dette giør boken tilgjengelig for et større publikum og gir den en nødvendig dybde.

Krigen indeni ser nærmere på hvordan krig påvirker mennesker, og Kimer, ved hjelp av sine "fiksere» (i hovedsak den ukrainske journalisten Vova), gir leseren en ærlig og brutal beskrivelse av utviklingen i Ukraina - ofte rett fra frontlinjene. 


\section{KAREN-ANNA EGGEN}

Boka blir også etter hvert Kimers oppgjør med Europa og dets ledere som raskt lot konflikten og krigen vike for andre hendelser som for eksempel terrorhandlinger i Paris og flyktningestrømmen fra Syria. Dette er også et interessant tankekors, da hun utfordrer tendensen til å vende oppmerksomheter vekk fra det som i dag har blitt en «kald krig» i Øst-Ukraina og som har krevd langt større tap av menneskeliv enn terrorhandlinger ellers i Europa. Og, ikke minst, fra at dette er en pågående krig $i$ Europa. Kimer stanser imidlertid resonnementet her med å påpeke at Minsk-avtalene til dags dato har vist seg svært lite effektive.

Kimer har dekt Russland og de tidligere sovjetstatene for DR siden slutten av 2009 og har studert russisk i St. Petersburg. Det er tydelig at hun har inngående kjennskap til kultur og historie, noe som gir boka et faglig løft og leseren et dypere innblikk i russisk og ukrainsk kultur. Det er ikke lystig lesning når det gjelder den retningen Ukraina har utviklet seg i siden begynnelsen av 2014, men Kimer åpner avslutningsvis opp for at en ser kimen til positive endringer, men da i form av «forbedringer blant menneskene, ikke systemene» (s. 315). Kanskje blir skildringene tidvis noe enkle, og noen steder kommer det etter min mening avsnitt som ikke tilføyer historiene merverdi. Dette blir imidlertid småplukk i det som ellers er et viktig og tidsriktig bidrag til forståelsen av krisen i Ukraina, og et bidrag som bringer leseren nærmere en forståelse av «krigens væsen». 